\title{
Interactions between individual, household, and fishing community resilience in southeast Brazil
}

\author{
Marta Leite $^{1}$ Helen Ross $^{2}$ and Fikret Berkes ${ }^{1}$
}

\begin{abstract}
Resilience is recognized as a multilevel phenomenon, yet few studies have examined how the levels interact. This is partly because individual-level resilience and social-ecological systems resilience have developed in different fields. Here we explore the shocks and stresses experienced by a fishing community and its members, their responses, and how resilience features were expressed at individual, household, and community levels in southeast Brazil. First, both connections and disjunctions were found between resilience features at the three levels. Second, the greater resilience of certain individuals and households within the community contributed to increased social differentiation and reduced overall community resilience. Third, understanding resilience at multiple levels highlighted the consideration of persistence, adaptation, and transformation processes as potentially complementary, rather than conflicting. These conclusions underline the importance of understanding the particularities of each level, and how they relate to one another. A multilevel approach provides insight into aspects of resilience that would not be apparent if only one level were explored.
\end{abstract}

Key Words: adaptation; Caiçara; multilevel resilience; persistence; shocks and stresses; small-scale fisheries; transformation; vulnerability

\section{INTRODUCTION}

Coastal ecosystems are impacted by many drivers of change, a number of them directly affecting small-scale fisher livelihoods (Jentoft and Chuenpagdee 2015). Examples include overfishing, intensifying tourism and real estate speculation, out-migration and immigration, competition with large-scale fisheries, climate change, and degradation of terrestrial and marine ecosystems (Badjeck et al. 2010, Hanazaki et al. 2013). Aggravating these struggles are restrictive fishing policies such as marine protected areas, quota systems, and closed seasons, among the many of the technical "fixes" adopted by managers (Degnbol et al. 2006). Yet, despite these challenges, many small-scale fishers remain in fisheries (Allison and Ellis 2001, Coulthard 2008). Understanding the processes by which fishers respond and adjust to change is fundamental to mitigating the negative impacts of change in their communities and their ways of life (Trimble and Johnson 2013).

Resilience thinking offers a valuable lens to understand responses to multiple, and often concurrent, shocks and stresses brought by change. Shocks (or perturbations) can be defined as abrupt and often unexpected events, usually outside the range of expected variability, and stresses as ongoing pressures (Turner et al. 2003, Marschke and Berkes 2006). Resilience is a concept that developed simultaneously in different academic fields, including socialecological systems (SES) and psychology of development and mental health, as well as in certain policy arenas such as disaster management (Brown and Westaway 2011, Maclean et al. 2014, Brown 2016). The common thread among these different treatments of resilience is "the ability to successfully deal with change ... a characteristic that can be applied to individuals, communities, states, ecosystems or linked social-ecological systems, tightly coupled systems of people and environment" (Brown 2016:2).

The social-ecological systems literature defines resilience as the capacity of an SES to withstand shocks in order to maintain the same basic identity, structures, functions, and feedbacks (Gunderson and Holling 2002, Folke 2006). Here, the idea of resilience as maintaining the same structure and identity contrasts with the transformation of the system (Brown 2014). The concept of "panarchy," which describes SES as composed of nested levels and cross-scale interactions, e.g., in time and space, is central to resilience thinking. The multiple levels of a panarchy are influenced by processes occurring at other levels, as well as inside each level (Gunderson and Holling 2002). Many levels may play important roles in fisheries, from the individual, e.g. the fisher, to the global, e.g., international shrimp markets, with the potential that all levels are interacting and responding to these shocks, stresses, and/or opportunities (Berkes and Ross 2016). As Gelcich et al. (2010) show with respect to a managed transformation in Chilean fisheries governance, interactions among levels over time can be crucial. These interactions will have important impacts on how different levels of a system resist change, adapt, or transform. Here we deal with three levels: individual, household, and community.

First, individual resilience refers to a person's abilities to beat the odds and take positive life trajectories despite being exposed to adversity, hardships, and trauma (Luthar 2006, Buikstra et al. 2010). The literature that is concerned with the resilience of individuals derives from the fields of psychology of development and mental health (Brown and Westaway 2011, Berkes and Ross 2013). The process of developing resilience encompasses interactions and adjustments of the individual with both social and physical environments, alongside particular personal, emotional, and cognitive attributes (Luthar 2006, Schoon 2006). Here, vulnerabilities, as well as protective factors, are crucial (Luthar 2006). Vulnerabilities relate to factors that magnify conditions of risk, e.g., poverty and political instability, and protective factors are those that minimize the effects of risk, e.g., high neighborhood quality and social networks of support (Luthar 2006, Masten and Obradović 2006). Particularly, caring parents and being part of a stable home have been identified as central factors enhancing children's ability to overcome traumas (Wright et al. 2013). Therefore, one might assume that a resilient household assists individuals to overcome life adversities. 
Second, household resilience, a concept used less frequently in the literature, tends to be restricted to specific issues, such as food security (Alinovi et al. 2009, 2010) or climatic events (Nguyen and James 2013, Opiyo et al. 2014). For example, Alinovi et al. (2009) propose a methodology based on household resilience (as opposed to vulnerability) to food insecurity. The model considers many variables including income, access to food, assets, access to public services, and social safety nets, where stability and adaptive capacity are variables that cut across all other variables. However, their analysis of resilience does not approach household resilience more broadly (or address simultaneously occurring shocks and stresses) as the literature on individual and community resilience often does. Resilient households may be expected to add up to resilient communities, but this may not be necessarily so.

Third, community resilience can be defined as the "existence, development and engagement of community resources by community members to thrive in an environment characterized by change, uncertainty, unpredictability, and surprise" (Magis 2010:401). A related concept is social resilience, "the ability of groups or communities to cope with external stresses and disturbances as a result of social, political and environmental change" (Adger 2000:347). Here, whatever the level considered, community or social, collective resilience involves agency on the part of the community, including ability to self-organize (Berkes and Ross 2013).

There have been several attempts to explore the relationships between resilience at different social and ecological levels (Brown and Westaway 2011, Berkes and Ross 2013, 2016, Maclean et al. 2014, Brown 2016). Buikstra et al. (2010) explored relationships between individual and community resilience in an Australian rural context, identifying 11 resilience-promoting factors common to individual and community resilience. The main ones were networks of support and sense of belonging to a community, learning from experience, early experiences, environment and lifestyle, infrastructure and support services, sense of purpose, diverse and innovative economy, embracing differences, beliefs, and good leadership. The authors concluded that factors contributing to resilience at the individual and community levels were, for the most part, common to both.

In another example, Marschke and Berkes (2006) employed a multilevel approach to study fishing household resilience in Cambodia and found that the general features that affected households also affected the resilience of the community at large: learning to live with change and uncertainty; nurturing learning and adaptation though ecological and social memory; and creating opportunity for self-organization. However, the specific resilience-building strategies observed were quite different at the three levels examined, household, village, and nation. Berkes and Ross (2016) used panarchy as a theoretical framework to explore the interactions between resilience at multiple levels, and found that the relationships between different levels are not necessarily neatly nested. Each level tended to interact most strongly with adjacent levels, but in some cases, e.g., pandemics, there were direct vertical "jumps" from local to global, bypassing other levels.

The importance of interactions among levels within a socialecological system is well recognized and theorized (Gunderson and Holling 2002, Folke et al. 2010, Berkes and Ross 2013, 2016,
Brown 2016). But empirical studies in social sciences have produced mixed results; the actual nature of these interactions is not well known. Moreover, what literature does exist emphasizes the connections of resilience at different levels, rather than their possible disjunctions. The assumption that resilience at different levels is necessarily interconnected needs further examination. The objective of this paper is to address this gap by studying responses to shocks, stresses, and new opportunities in a smallscale fishing community in Brazil since the 1970s. We draw on concepts from various disciplinary approaches to resilience in doing so.

\section{STUDY AREA}

The municipality of Ubatuba, situated in southeastern Brazil, on the north coast of the state of São Paulo encompasses an area of $71,078 \mathrm{~km}^{2}$, and as of $2017 \mathrm{had}$ an estimated population of 88,313 according to IBGE (The Brazilian Institute of Geography and Statistics). However, during the high tourism season (December to February, and during holidays), the area's population increases several-fold.

The study area comprises two contiguous neighborhoods: Lázaro and Saco da Ribeira, located on the southern coast of the municipality (Fig. 1). Approximately 500 families live in the community, including 43 fishing-dependent households. The research focused exclusively on the fishing community. The two neighborhoods were considered one community because there is no physical division between them, and the fishers and their families interact daily.

Fig. 1. Lázaro and Saco da Ribeira Community, Ubatuba, São Paulo, Brazil.

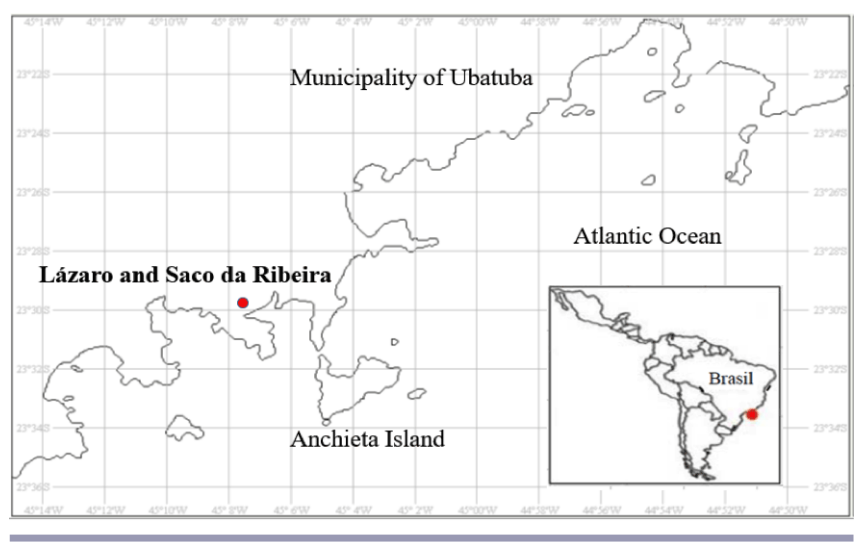

This community was chosen because as well as being one of the most active fishing communities of Ubatuba, the Saco da Ribeira Bay hosts the largest landing site of the municipality, where both small and large-scale fisheries are present. Fish landings, people selling and buying fish locally, and the presence of middlemen and fishmongers are a day-to-day routine. Moreover, the bay also hosts eight marinas and boathouses.

In this research, all participants were Caiçaras, a mixed-heritage group descended from Amerindians, Portuguese colonists, Africans, and other immigrants such as Japanese (Begossi 1998). The Caiçara of the region historically relied on the cultivation of cassava, sugarcane, fruits, e.g., bananas and oranges, and coffee, 
as well as on fishing, hunting, and the extraction of forest products such as wood for building fishing canoes for livelihoods (Diegues 2004; Denadai et al. 2009, unpublished manuscript, http://www. pesnochao.org.br/memorias/ebook_com_quantas_memorias_sefaz uma canoa.pdf).

Fishing has played an important subsistence and social role in Caiçara communities for the three centuries of their existence, but the earliest records of fishing as an economic activity date back only to the early 1900s, with the traditional mullet (Mugil platanus) fishery (Diegues 1974). In the 1940s, Japanese immigrants introduced a pound net fishery, locally called cercos flutuantes (Begosi 2006, Idrobo 2014), which is still used in many Caiçara communities. In the 1960s, the first trawlers, targeting shrimp, arrived in Ubatuba, and by the early 1970s, fishing had become one of the main local economic activities (Diegues 1983).

During the 1970s, with the construction of the coastal highway connecting the study area with cities such as Santos, São Paulo, and Rio de Janeiro, Caiçaras began experiencing rapid social and economic changes. The influx of immigrants and tourists resulted in a growing demand for seafood resources and increasing pressure on important local commercial species, including sardines, shrimps, sharks, and several fish stocks. Many of these stocks were significantly reduced because of perverse incentives and lack of proper management, including policy incentives in the 1970s to reduce interest rates and to encourage investment in industrial fishing enterprises in Brazil (Abdallah and Sumaila 2007).

The 1970s also saw the creation of state parks and the emergence of new conservation measures in the region, which led to regional and local conflicts regarding the use of natural resources. Over $80 \%$ of the land base in Ubatuba falls within the Serra do Mar State Park and other protected areas, designed to protect the remnants of the native Atlantic Forest. Further, in the late 1990s, large-scale commercial fisheries started accessing the coastal areas of São Paulo state, and soon fish scarcity became a significant challenge for artisanal fishers. As a consequence, the coast of Ubatuba was included as part of a marine protected area, created in the state of Sao Paulo in 2008. Despite some descriptions in the literature of these impacts on small-scale fisher livelihoods over the last 50 years, studies on fishing communities' struggles and resilience strategies remain rare (see Prado et al. 2015).

Both small-scale and industrial fisheries land their catches in Ubatuba, with small-scale predominating in shallower coastal waters (Leite 2018). Most small-scale fisheries are multispecies, catching several species using different fishing gear according to seasons and availability. The main fishing gear are small gillnets, pound nets, hook and line, hand jigs, and small (about $7 \mathrm{~m}$ ) shrimp trawlers (Leite 2018). Some of the main commercial species are sea-bob shrimp (Xiphopenaeus kroyeri) and white shrimp (Litopenaeus schmitti), whitemouth croaker (Micropogonias furnieri), several weakfishes (Cynoscion jamaicensis, Cyonoscion striatus, Cynoscion acoupa, Macrodon ancylodon), species from the Caranx and Scomberomorus genera (Caranx crysos, Caranx hippos, Scomberomorus brasiliensis, Scomberomorus cavalla), groupers (e.g., Epinephelus marginatus), and squids (Doryteuthis plei and Doryteuthis sanpaulensis; for a more comprehensive list, see Leite 2018).

\section{METHODS}

In this study multiple methods, including participant observation, household surveys, open-ended and semistructured interviews, and focus groups were employed. Fieldwork was conducted over one year, from July 2014 to July 2015. Only households that relied on fisheries for income were approached to participate in this research; recreational or occasional fishers were not included. Out of the 44 fishing-dependent households within the community, 41 participated. Three households opted to not take part in this study, for various reasons, including sickness of a family member, and lack of interest in taking part in research projects.

Participant observation (Bernard 2006, Hay 2008, Creswell 2009) was used as a way of building familiarity with the community and its members, and learning the social context for data obtained by other methods. Subsequently, household surveys, following the questionnaire developed by Hanazaki et al. (2013), were conducted with fishers or fishers' wives (whomever was available) belonging to the 41 participating households. The main objective was to identify fishing households' profiles. Next, open-ended interviews (Bernard 2006, Creswell 2009) were conducted with 16 community members (6 women and 10 men) who had also participated in the household survey. This allowed for the identification of the most relevant shocks, stresses, and new opportunities faced by local fishers and their families over time.

Based on the data gathered through the previous methods, semistructured interviews (Hay 2008, Creswell 2009) were developed to explore resilience processes at individual, household, and community levels. Thirty participants ( 16 men and 14 women) were purposively selected to represent different genders, fishinggear groups, education levels, wealth status, and age-groups, so as to cover the diversity of fishers in the study area. Age-groups were divided into youth (18-29 years), adults (30-59 years), and elders (over 60 years). Last, three focus groups were conducted: with men (11 fishers, adults and elders), women (six fisher wives, adults and elders), and youth (seven participants, three women and four men), to gather additional data on community resilience, with an emphasis on community-level relations and fishers' engagement in fisheries management.

\section{RESULTS}

\section{Shocks and stresses}

Fishers and their families reported experiencing many shocks and stresses after the 1970s. Although several stressors were not directly associated with fisheries, we focused on the shocks and stresses related to fishing (Table 1). These were identified during open-ended interviews, and confirmed through follow-ups. Other shocks and stresses, relevant to individual resilience, are explored below. For a complete view of all shocks and stresses identified by participants, refer to Leite (2018).

In Table 1 we deliberately chose not to differentiate between shocks and stresses because many of the shocks to older generations have turned into current stressors. For example, the creation of fishing no-take areas initially represented a loss of rights and therefore a shock, but is currently experienced as a stress because fishers frequently conduct illegal fishing and so risk arrest to remain productive. Meanwhile illegal fishing can lead to a shock if the fisher is apprehended by enforcement agents. 
Table 1. Shocks and stresses described by participants, responses and consequences for livelihoods.

\begin{tabular}{|c|c|c|c|}
\hline Shocks and stresses & Description & Response & Consequences \\
\hline Fish scarcity & $\begin{array}{l}\text { Declines in fish stocks in Ubatuba have } \\
\text { been reported by fishers and scientists } \\
\text { for decades. }\end{array}$ & $\begin{array}{l}\text { Diversify to livelihoods focused on } \\
\text { tourism activities. } \\
\text { Diversify to target different species. }\end{array}$ & $\begin{array}{l}\text { Impoverishment of households that have } \\
\text { less access to financial resources to invest } \\
\text { in diversification. }\end{array}$ \\
\hline $\begin{array}{l}\text { Creation of fishing } \\
\text { no-take areas }\end{array}$ & $\begin{array}{l}\text { Banning of important fishing grounds } \\
\text { has had a significant impact on fishing } \\
\text { activities. }\end{array}$ & $\begin{array}{l}\text { Intensified use of other fishing grounds } \\
\text { that are "not as good." } \\
\text { Illegal fishing. }\end{array}$ & $\begin{array}{l}\text { A widespread sense of injustice. } \\
\text { Distrust of government environmental } \\
\text { agencies. }\end{array}$ \\
\hline Illegal fishing & $\begin{array}{l}\text { Many fishers chose to risk fishing } \\
\text { illegally, both in no-take areas and closed } \\
\text { seasons. }\end{array}$ & $\begin{array}{l}\text { Fishing at night without lights to reduce } \\
\text { the risk of detection. }\end{array}$ & $\begin{array}{l}\text { Arrest, seizure of fishing gear and catch, } \\
\text { and fines. } \\
\text { Conflicts with enforcement agents. } \\
\text { Increased risk of accidents at sea. }\end{array}$ \\
\hline $\begin{array}{l}\text { Level of bureaucracy } \\
\text { to obtain necessary } \\
\text { fishing licenses }\end{array}$ & $\begin{array}{l}\text { Fishers find paperwork excessive and an } \\
\text { obstacle to proper registration and legal } \\
\text { documentation. }\end{array}$ & $\begin{array}{l}\text { Fishing undocumented or with expired } \\
\text { licenses. }\end{array}$ & $\begin{array}{l}\text { Arrest, seizure of fishing gear and catch, } \\
\text { fines. } \\
\text { Conflicts with enforcement agents. }\end{array}$ \\
\hline $\begin{array}{l}\text { Lack of available crew } \\
\text { members }\end{array}$ & $\begin{array}{l}\text { Growing difficulty in finding crew } \\
\text { members because: } \\
\text { (1) Substance abuse affecting fishers' } \\
\text { capacity to commit to the job; } \\
\text { (2) Most youth are not interested in } \\
\text { fishing. }\end{array}$ & $\begin{array}{l}\text { Fishing alone, or else risk working with } \\
\text { crew members who compromise safety at } \\
\text { sea, or who cannot be relied on to show } \\
\text { up regularly. }\end{array}$ & $\begin{array}{l}\text { Fishers placing their boats on the } \\
\text { market. } \\
\text { Abandoned boats on the coast. }\end{array}$ \\
\hline
\end{tabular}

Note: More details and a longer list of shocks and stresses identified by participants are documented in Leite (2018).

Importantly, participants' responses to such stresses and shocks did not always occur at the organizational level where the given shock/stress took place. To elaborate, Table 2 presents the main level affected by each shock/stress and the main level where responses occurred. The main level affected by a shock/stress was not necessarily the only level impacted. For example, shocks and stresses that affect individuals were very likely to affect their households, even if emotionally, e.g., fisher's wife worries when her husband fishes illegally. Additionally, shocks and stresses that affected the great majority of participants were considered impacts at the fishing community level. A clear pattern in this community was the absence of community-level responses to shocks and stresses that had impacts at the community level; responses seemed always to occur at the household and individual levels.

Although rapid change in the region brought on these diverse shocks and stresses, of equal importance were new opportunities, and responses, that arose. Participants identified new opportunities during open-ended and semistructured interviews. Table 3 presents a collection of new opportunities, along with different responses and corresponding consequences for local livelihoods. The following explores individual, household, and community resilience processes related to the stresses and shocks described above, as well as additional level-relevant challenges.

\section{Individual resilience: protective factors and vulnerabilities}

Here, we consider shocks and stresses that are significant when approaching resilience from a psychological perspective. For example, elders experienced a vast array of shocks or traumas, including loss of land and of rights to access natural resources (including agriculture, hunting, and important fishing grounds), while the younger generations face obstacles related to drug abuse and absence of life goals. Indeed, the youth focus group revealed that only two participants out of seven had a clear idea of what they would like to achieve in the near future. Table 4 summarizes the protective factors and the vulnerabilities found, as well as the genders and ages most affected.
Interestingly, 8 out of 30 individuals (adults, both male and female) who participated in the semistructured interviews reported seeking psychological counseling for themselves or household members, either recently or in the past. This number is particularly high considering there was no specific question nor probe about psychological counseling during interviews, and thus one might reason that the rate of occurrence is even greater. Reasons varied, including women feeling their freedom was constrained by husbands, traumas caused by past experiences of domestic violence, mental health problems, and the loss of fishing rights because of illegal fishing. The search for psychological counseling was more common among women (5) than men (3). A key informant suggested an explanation:

\section{Men have the sea, and for them, the sea is like therapy. It makes them feel better about themselves and their problems. We, women, stay [on land] and have no escape like them. (Adult female)}

Indeed, when asked about the meaning of fishing, all fishers (including three fisherwomen) described the sea and fishing with a reverence beyond what could simply be ascribed to an income source. They described their intimate contact with nature as well as being physically active and greeting the constant challenges of the sea as reinvigorating. Some important aspects of fishing activities cited included stress reduction, positive emotions, feelings of freedom, and the pride in a good catch:

I am retired, yet I do not want to stop fishing, I know that the day I stop is the day I die. Fishing is not just about money; it is health. To breathe the sea air! The waves wash our problems away. (Older male fisher)

In the sea I am my own boss. Many times I have a bad day, a bad catch, even though it is good because I feel free, there is no one to tell me what to do, only my wife [laughs]. (Adult male fisher) 
Table 2. Stresses and shocks described by participants, the main level affected, responses, and the level at which responses took place.

\begin{tabular}{|c|c|c|c|}
\hline Shocks and stresses & Main level(s) affected & Main coping/adaptation response & Main level(s) of response \\
\hline Fish scarcity & Community level & $\begin{array}{l}\text { Livelihood diversification } \\
\text { Greater focus on tourism activities }\end{array}$ & Household level \\
\hline $\begin{array}{l}\text { Creation of fishing } \\
\text { no-take areas }\end{array}$ & Community level & $\begin{array}{l}\text { Intensified use of other fishing grounds } \\
\text { Illegal fishing }\end{array}$ & Individual and household levels \\
\hline Illegal fishing & Individual level & $\begin{array}{l}\text { Fishing in banned areas/seasons (especially at } \\
\text { night without lights to reduce the risk of } \\
\text { detection) }\end{array}$ & Individual level \\
\hline $\begin{array}{l}\text { Level of bureaucracy to obtain } \\
\text { necessary fishing licenses }\end{array}$ & Household level & Fishing undocumented or with expired license & Individual level \\
\hline Lack of available crew members & Individual level & $\begin{array}{l}\text { Fish alone, or else risk working with crew } \\
\text { members who might compromise safety at sea, } \\
\text { or who cannot be relied on to show up } \\
\text { regularly }\end{array}$ & Individual level \\
\hline
\end{tabular}

Despite such high importance placed on the sea and fishing activities for fishers' psychological resilience, the creation of restrictive fishing policies (such as no-take fishing areas and closed seasons) has exposed fishers to vulnerabilities not previously experienced. Illegal fishing brought many cases of power abuse by enforcement agents, as cited by the majority of fishers. These conflicts were characterized as an imbalanced power dynamic, based on fear and subordination. Participants explained that it is common for fishers to be approached by agents with firearms, even when fishing legally. The case below reflects on how relationships with enforcement agents can have significant impacts on fishers' psychological health:

My father was caught fishing illegally when I was young.
He has a strong personality. He got in a discussion with
the enforcement agent because he thought it [fishing] was
his right. He got bitten [literally] and offended by that
man. He lost everything that day: gear, catch, his pride.
My father starteddrinking. He never went back to fishing.
He couldn't even take care of himself, always drunk...
My mother started working more and more, buying and
processing shrimp from other fishers; she even had many
other women working for her. My father took more than
10 years to stop drinking. I helped my mother selling the
shrimp at home. (Adult female)

As shown above, in instances when fishers engaged in discussions with agents, consequences could be significant, ranging from predefined punishments (arrest, seizure of fishing gear and catch) to verbal and physical abuse (violent threats and beatings). Conversely, according to participants, if fishers show subordination, a second chance may be given:

They got me fishing close to the Anchieta Island [no-take area]. I am sure I was out of the restricted area, but they said I was in it. I just put my head down and said "Yes Sir" to everything they said. I could not afford to lose my gear. They said I could go, and that they did not want to see me around anymore, or I would regret it. (Adult male fisher)

Mistreatment by enforcement agents, as well as low-job satisfaction and higher rates of substance abuse among crew members contributed to youths' lack of interest in engaging with fishing activities. Indeed, the youth focus group participants agreed that some of the reasons that made fishing unattractive to them included fish scarcity, restrictive policies, laborious bureaucracy to obtain a fishing license, and on top of all that, fear of conflict with enforcement agents. The lack of interest among youth, together with the difficulty in finding reliable crew members, represented a challenge especially for trawler fishers who frequently hired an extra fisher to assist the main fisher (or master). Even though youth generally showed little interest in fishing, with potential implications for the future of artisanal fishing in the area, households have demonstrated notable resilience in finding ways to retain fishing as part of their livelihood portfolios.

\section{Household resilience: diversification and flexibility}

Despite the fact that all participant households were able to maintain fishing as a source of income, some were merely coping, while others demonstrated an ability to adapt positively to changing circumstances. There were several attributes common to those able to better adapt: (1) possessing land and houses to rent to tourists; (2) owning their boats and diverse fishing gear; (3) having freezers to store catches (and therefore sell the catch directly to consumers); (4) coupled formal education and local knowledge; and (5) having extended families in the community. Importantly, livelihood diversification, together with women's contributions to household income, played a crucial role in fishing household resilience. Having an alternative source of income (both from fishers diversifying activities and women's wage jobs) frequently provided the financial security required for fishers to continue investing time and money in fishing activities.

Households with less access to the assets described above used shorter term and less secure activities. Examples include construction work as day laborers, working as occasional maids or babysitters, working at landing sites to handle catches of largescale vessels, and relying on middlemen to sell their fish. Among these households, it was common to find an "if, then" type of strategy (Table 5).

When livelihood diversification becomes a prominent response to change, variation in household capacities to take advantage of new opportunities can intensify social stratification. Moreover, some opportunities represented gains for some but a loss for others. Marinas and boathouses, for example, brought 
Table 3. New opportunities that arose in the study area after the 1970s, responses and consequences for participants' livelihoods.

\begin{tabular}{|c|c|c|}
\hline Opportunities & Responses & Consequences \\
\hline $\begin{array}{l}\text { Tourism and increased } \\
\text { job opportunities }\end{array}$ & $\begin{array}{l}\text { After the 1970s Caiçaras started engaging in tourism-related } \\
\text { activities such as working in grocery stores, hotels, } \\
\text { construction, home services, selling pastries, renting out } \\
\text { beach equipment, etc. }\end{array}$ & $\begin{array}{l}\text { Livelihood diversification. Locals that were formerly } \\
\text { dependent on fisheries, small-scale agriculture, and hunting, } \\
\text { increasingly diversified to tourism-related activities. }\end{array}$ \\
\hline Renting houses to tourists & $\begin{array}{l}\text { Households are maximizing the construction of rental } \\
\text { housing on their lands to cater to tourist demands. Many } \\
\text { households had one or more houses used for renting on } \\
\text { their properties. }\end{array}$ & $\begin{array}{l}\text { Important income source in high seasons and holidays. } \\
\text { Households that do not have land are excluded from this } \\
\text { opportunity. } \\
\text { Increased social differentiation. } \\
\text { Properties are continuously subdivided into smaller parcels. }\end{array}$ \\
\hline $\begin{array}{l}\text { Guiding tourists on } \\
\text { fishing, beach, or island } \\
\text { excursions. }\end{array}$ & $\begin{array}{l}\text { Many participants combined their traditional knowledge/ } \\
\text { skills with learned skills/knowledge to take advantage of } \\
\text { tourism, e.g., navigation and fishing grounds knowledge } \\
\text { with new ability of how to deal with tourists and administer } \\
\text { budgets. }\end{array}$ & $\begin{array}{l}\text { Fishers found a way to continue fishing and to apply their } \\
\text { knowledge in this direction. Nevertheless, only fishers that } \\
\text { have motorized boats and gear, and financial assets to adapt } \\
\text { their boats to accommodate tourists, can pursue this } \\
\text { opportunity. }\end{array}$ \\
\hline $\begin{array}{l}\text { Working as a marinheiro } \\
\text { (captain-for-hire) for } \\
\text { yacht owners }\end{array}$ & $\begin{array}{l}\text { Working as a marinheiro for wealthy yacht owners. The area } \\
\text { had eight marinas/yacht clubs in } 2016 \text {. Fishers are investing } \\
\text { in education because they need good literacy to pass special } \\
\text { license test. }\end{array}$ & $\begin{array}{l}\text { Marinas create stronger social stratification locally. } \\
\text { Marinheiros are better paid than those engaged in other local } \\
\text { activities. The job offers the security of a monthly wage, and } \\
\text { at the same time the freedom to fish whenever they are not } \\
\text { on duty. }\end{array}$ \\
\hline
\end{tabular}

opportunities for many fishers to work for high-end tourists as marinheiros (in charge of sailing and maintaining the yacht). From these fishers' perspective, the development of high-end boat tourism improved their livelihoods. Other community members, however, have a different viewpoint:

The marinas brought a lot of jobs to our place, jobs as marinheiros, marinheiros' assistants, mechanics, electrician, security guards... I am a marinheiro, and so are my brother and brother-in-law. My son is my assistant. (Adult male fisher)

Despite all the jobs, the marinas introduced a lot of pollution to our sea, and we lost access to the Saco da Ribeira bay [location of most yacht clubs and boat houses] where we used to collect mussels, swim, and fish. (Older female)

A central component of diversification was the role of women's contributions to household resilience. Out of 41 households, 21 $(51 \%)$ had women contributing financially to the household income by engaging in activities not directly related to fisheries. Women contributed to household income through both paid jobs $(76 \%)$ and by conducting their own businesses $(24 \%)$. Paid jobs included housekeeping, teaching assistantships, and working in restaurants, among others. Businesses included making pastries to sell at the beach or at home, and working out of small family shops.

Also contributing to household income, five women went out fishing with their husbands, and one of these was considered a top fisher in the community. All five fisherwomen were also involved with postfishing activities (cleaning and packing the fish, selling fish, and managing budget). Eleven other women did not fish, but were responsible for cleaning and/or selling their husbands' catches from home. Those women who had paid jobs normally earned less income per year than the men; however, their income sources were generally more stable compared to the unpredictability of fishing. A fisher's wife explained:
My job, as housekeeper, is what makes us sure that we will pay the bills at the end of the month. When my husband has a good fishing day, it is great, good money, but there are hard months too. Sometimes the fish just disappear from the water, and the catch does not pay the investment in going fishing, you know? (Adult female)

In addition to contributing to household income, women also demonstrated awareness of the need to save money for future "surprises." At the time of the fieldwork, less than $20 \%$ of households had debts (only two of these over US\$5000) demonstrating participants' general capacity to maintain financial control over their expenses. Yet, only $10 \%$ of participants had a savings account for "emergencies," all of them being women. Other women expressed their frustration in not having any savings, and a sense of insecurity to deal with future uncertainties. Nevertheless, many participants would invest in what they called "other forms of savings." For example, common statements included, "I do not have a savings account, but I have land, and in case of an emergency, I can sell it" (Adult male fisher); "I do not trust banks, and the interests [rates] are not very good anyway. If I ever need to sell my second house, I will" (Older male fisher); "My boat is my savings account" (Adult male fisher).

Finally, combining strategies, such as those presented in Table 5, provides households with a degree of flexibility to deal with uncertain events, such as a bad catch and tourism fluctuations. In this sense, households in general managed to find ways of responding to changes triggered by economic development, some in more secure ways than others. Yet, development and tourism brought clear implications for resilience at the community-level.

\section{Community resilience: lack of community cohesion and collective action}

When asked how economic development had affected the community over the last several decades, participants characterized change in terms of trade-offs. All three focus groups (with youth, women, and men) recognized a trade-off between 
Table 4. Protective factors and vulnerabilities identified as affecting individual resilience.

\begin{tabular}{|c|c|c|c|}
\hline Protective factors & Gender/Age group & Vulnerabilities & Gender/Age group \\
\hline $\begin{array}{l}\text { Household and extended family } \\
\text { support }\end{array}$ & $\begin{array}{l}\text { Both genders, most commonly } \\
\text { adults and older males }\end{array}$ & $\begin{array}{l}\text { Constraints on freedom due to } \\
\text { restrictions on fishing rights }\end{array}$ & $\begin{array}{l}\text { Both genders, most commonly adult } \\
\text { and older males }\end{array}$ \\
\hline Psychological counseling & $\begin{array}{l}\text { Both genders, most commonly adult } \\
\text { females }\end{array}$ & $\begin{array}{l}\text { Illegal fishing and conflicts with } \\
\text { enforcement agents }\end{array}$ & Adults and older males ${ }^{\dagger}$ \\
\hline $\begin{array}{l}\text { Fishing as an invigorating } \\
\text { environment }\end{array}$ & $\begin{array}{l}\text { Both genders, most commonly adult } \\
\text { and older males (three fisherwoman } \\
\text { mentions) }\end{array}$ & $\begin{array}{l}\text { Substance abuse and easy access to } \\
\text { illegal drugs in the community }\end{array}$ & $\begin{array}{l}\text { Both genders, most commonly male } \\
\text { adults and youth }\end{array}$ \\
\hline Faith and church circles & $\begin{array}{l}\text { Both genders, most commonly adult } \\
\text { females and youth }\end{array}$ & $\begin{array}{l}\text { Domestic violence (verbal and } \\
\text { physical) }\end{array}$ & $\begin{array}{l}\text { Both genders, most commonly older } \\
\text { females and youth }\end{array}$ \\
\hline Friendship ties & $\begin{array}{l}\text { Both genders, most commonly adult } \\
\text { females and youth }\end{array}$ & & \\
\hline Formal education & $\begin{array}{l}\text { Both genders, most commonly } \\
\text { adults and youth }\end{array}$ & & \\
\hline Local knowledge & $\begin{array}{l}\text { Both genders, most commonly adult } \\
\text { and older males }\end{array}$ & & \\
\hline Autonomy & Both genders, adults and older & & \\
\hline
\end{tabular}

economic development, and community cohesion and collective action. For instance, all agreed that employment opportunities had improved, and this effect of development and tourism was viewed positively. However, these opportunities also led to loss of community social capital through the erosion of traditional norms and customs. Economic development permitted community members to be less dependent on one another, initiating a shift toward more individualistic lifestyles. Additionally, economic development, and especially opportunities related to tourism, intensified social stratification because not all could take advantage of these new opportunities.

As a consequence of both more individualistic lifestyles and stronger social stratification, community networks became weaker and in some cases lost altogether. An example is the gathering known as multirões that used to unite locals to construct a house for a community member. Community-wide multirões no longer occur; instead, contractors are hired or construction is simply carried out by the family. Certain fishing activities also relied on collective work. Although the beach seines were owned by a handful of fishermen, this fishing method required large numbers of fishers and helpers to haul the net and sort the fish, men, women, and children alike. The fish (mainly mullets) were then divided according to a formula, all participants receiving part of the catch. Fishing with beach seines has been banned by the government since the 1980s, supposedly because of a high incidence of juveniles in the catch. Nevertheless, one fisher stated the following:

\section{Even if the beach seine was allowed, it would not happen} as often because now everyone has their own boats and gillnets, they do not need to come together any more. (Older male fisher)

Participants also explained that networks of support have shifted, with less reliance on the broader community of fishers than in the past. Indeed, when asked who participants relied on in difficult times, the vast majority pointed either to their immediate household or extended family members. Focus groups confirmed churches as influential groups within the community. As participants explained, churches have diversified, with one Catholic and three evangelical operating in the area, and they have also gained significantly in strength. As a consequence, the once more unified fishing community has fractured along lines of church affiliation, ultimately weakening the fishing community as a whole.

However, some kinds of community-level coordination and rule making were evident. For example, informal rules did exist when defining where an individual fisher's gear and boats (skiffs and canoes) could be stored on the beachfront, and for trawlers, on the landing spot. Moreover, a moral code stipulates any fisher under distress at sea shall be assisted without question. All fishers strongly agreed with this rule. Exchanging information about fishing grounds and resources is also a common habit among local fishers; however, information regarding good catch locations is shared only with closest friends and fishers in the family.

Aside from concerns such as these, fishers of the study area conducted no formal meetings. Even though members of the Ubatuba fishing community are bonded through shared ethnicity and culture, occupation, and extended family networks, there is no formal organization such as fishing associations or cooperatives, and few attempts to organize collectively. Until the end of fieldwork in July 2015, fishers were not engaged in any active organizations. Three fishers from the men's focus group commented on this lack of collective action: "We are small [smallscale fisheries], we have no power, no voice [insinuating there is no point to organize]" (Adult male fisher); "Fishers are not united here, there is no effort to come together to fight for the benefit of all" (Adult male fisher); "The hard part is to agree. Canoe fishers think differently from shrimp trawlers" (Older male fisher).

\section{DISCUSSION}

Findings from this research suggest that resilience at different levels (individual, household, and community) is manifested independently from the other levels, yet there are certain connections, and disjunctions, between some of the resilience features at the different levels. Confounding the analysis, the boundaries among the three levels were often hard to define. 
Table 5. "If, then" strategies adopted by households. Adult and older fisher quotations.

\begin{tabular}{|c|c|}
\hline If & Then \\
\hline If the catch is big & $\begin{array}{l}\text { then I sell to the middleman [prices fall, and normally others also have good catches, } \\
\text { making local markets saturated, less lucrative, and more competitive]. }\end{array}$ \\
\hline If the catch is small & then I sell at home to tourists [there is limited space for storage at fishers' houses]. ${ }^{\dagger}$ \\
\hline If the fish [species] caught has high market value & then we sell it directly to tourists, or keep it for special occasions [festivities]. \\
\hline If the fish [species] caught has low market value & $\begin{array}{l}\text { then I sell it to the middleman, or to other community members, or then, I share } \\
\text { more with friends and neighbors. }\end{array}$ \\
\hline If the large-scale fisheries land big catches, and the prices fall & then I buy fish from these fisheries and sell it locally. \\
\hline $\begin{array}{l}\text { When [If] there are sardine or pink shrimp landings [from large- } \\
\text { scale fisheries] I work landing their catches and get paid in cash } \\
\text { and fish. }\end{array}$ & $\begin{array}{l}\text { then I resell it to tourists [if shrimp] or to community members [if sardines or other } \\
\text { cheaper bulk fish]. }\end{array}$ \\
\hline
\end{tabular}

Households are made up of individuals, and are part of communities; thus, dealing with discrete levels risks oversimplification. Nevertheless, contemplating resilience at multiple levels allowed for a fuller understanding of the impacts of diverse drivers on individuals, households, and the broader fishing community.

Although many shocks and stresses that affected the community level to some degree also affected households and individuals, other shocks and stresses were particular to specific levels, or actors within levels, requiring different resilience strategies. For example, environmental policies and fish scarcity generally affected all levels. Diversifying income-generating activities thus became a common strategy, whereby the fisher, or other members of the household, involved themselves in different economic sectors as a way of reducing vulnerability and the risk of livelihood failure. Women frequently had a central role in a family's diversified income portfolio. Livelihood diversification, or engaging in activities outside fishing, is a commonly described strategy in the literature on coastal fishers' responses to socialecological changes (Ellis 2000, Allison and Ellis 2001, Grant et al. 2007). Hanazaki et al. (2013), found that Caiçara fishers in the Paraty area, north of Ubatuba, commonly combined fishing activities with tourism, day-wage jobs, agriculture, and commerce, among others. Similarly, Prado et al. (2015) found livelihood diversification, especially tourism, to be central to small-scale fisher livelihood resilience in the neighboring municipality of Angra dos Reis.

Livelihood diversification can be complex. Béné et al. (2003) describe two different forces driving livelihood diversification. In the first, called "diversification for accumulation," diversification appears to be associated with higher household well-being and is considered a proactive strategy generally pursued by wealthier households. In the second, "diversification for survival," diversification occurs as a form of coping with challenges or as a reactive response to crises (Béné et al. 2003). This research indicates that the two types of diversification can coexist: the same household could engage in both forms of diversification over time, depending on which household member is considered, and the context. That said, livelihood diversification toward tourism activities was a strategy generally pursued by wealthier households, characterizing "diversification for accumulation." Further, individuals who were able to diversify in secure ways were frequently more educated. Similarly, Islam and Chuenpagdee (2013) found that in mangrove fishing communities in Bangladesh, the better-off households were able to employ more effective resilience strategies than those with lesser financial resources. Thus, in both Ubatuba and the Bangladesh case, wealthier households seemed to demonstrate greater capacity to manage their own resilience pathways in times of crisis.

Moreover, individuals and households with stronger social capital, especially family-centered systems of support, were more capable of diversifying activities proactively. Blythe et al. (2014) also found family networks to facilitate adaptation processes among fishers in Mozambique. However, contrary to our findings, they showed that wealthier fishers tended to intensify fishing effort in response to declines in catches, while the poorer fishers normally diversified livelihood sources. A central difference between the two cases is the strong influence of tourism in Ubatuba after the 1970s, and the opportunities that arose from this new economic sector to "remain in the game" of fishing (Ross and Berkes 2014). In Ubatuba, fishers who kept fishing as their household's primary or sole source of income were frequently facing vulnerabilities such as substance abuse and impoverishment. Here, increased household resilience to stay "in the game" of fishing translated into decreased individual resilience.

Buikstra et al. (2010) identified resilience-promoting strategies common to individual and community levels in Australia, for instance pointing to networks of support as a common thread. In this research, networks of support were found to be essential to individual and household resilience, but these networks occurred mainly through family and church circles and not at the broader community level. In fact, churches, which contributed significantly toward individual resilience (especially for women), were also described as responsible for creating divisions among families belonging to different churches, undermining the resilience of the community as a whole. Buikstra et al. (2010) points to embracing differences and the existence of shared religious beliefs and practices as factors promoting resilient communities. This perhaps explains why in Ubatuba participants blamed the lack of acceptance of different beliefs as responsible for decreasing community cohesion, and consequently resilience. This is an important disconnection between resilience among individual and community levels. 
Fig. 2. Main resilience features among the three levels (individual, household, and community), and the connections and disjunctions among them. The red dashed boxes represent features that decreased community resilience. The black boxes represent features that contributed to the resilience of at least one level. The red dashed lines represent disjunctions, or "negative" connections, while the black lines represent "positive" connections among level-specific resilience features.

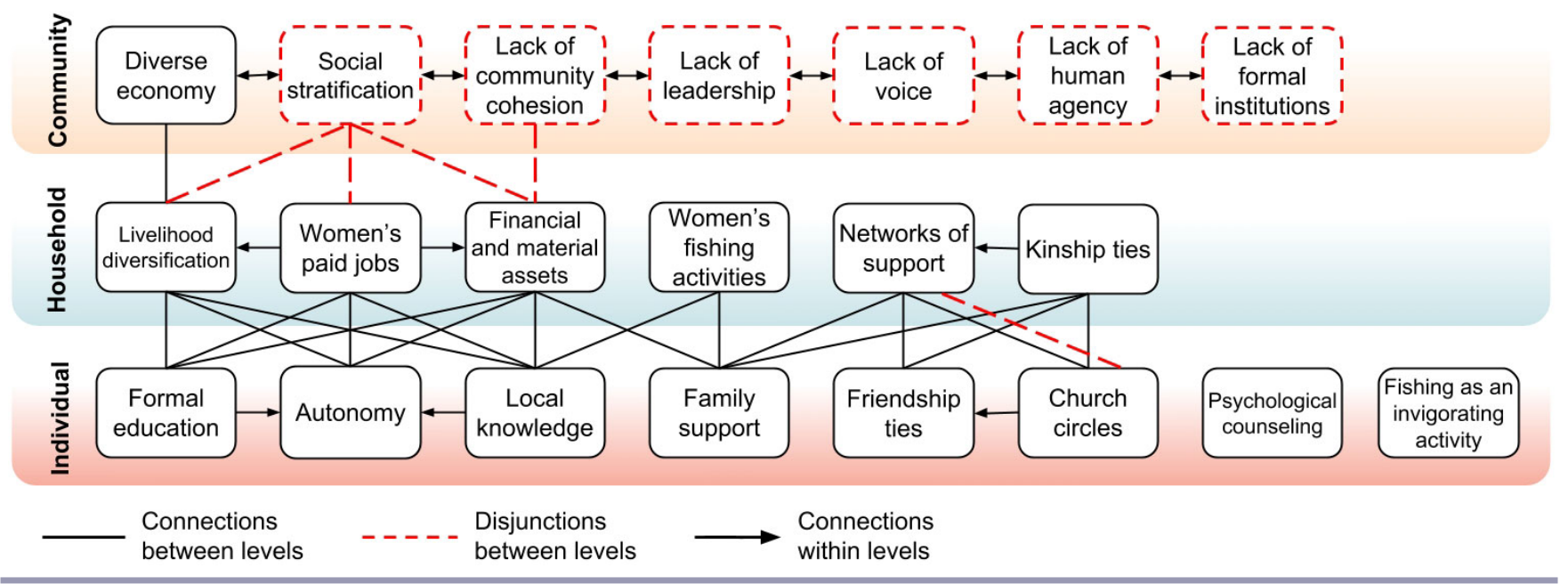

In a nutshell, resilience varied widely both within and across the three levels, depending on the shock, stress, or opportunity considered. For example, lack of resilience at the individual level did not necessarily translate into lack of household resilience, even when it affected the head of the family. This is best represented by the case where a fisher suffered from alcoholism, and yet the household responded with strength on account of the wife and daughter's efforts. Whereas one household member may have struggled to deal with adversity, the household remained remarkably resilient by maintaining fisheries as a livelihood source.

At the household level, resilience showed considerably less variability than the individual level. This may be because households managed to remain in the community and retain fishing as part of their livelihood portfolios, as opposed to many other Caiçara families who out-migrated to Ubatuba urban area or other cities. Moreover, despite wealth and standard-of-living differences, none of the surveyed households reported food insecurity. Even with diminished fish abundance and limited access to fish stocks, participants still reported considerable availability of fish. As in Paraty (Hanazaki et al. 2013), kinship ties and food-sharing appeared to have a role in maintaining food security across households. More generally, basic needs such as shelter, health care, and safe drinking water were also reportedly accessible for the great majority of participants. Nonexistent in the past, children and youth also have access to relatively good public school and daycare facilities within the community.

However, differences in the capacity of households for taking advantage of tourism-related opportunities increased social stratification, weakened social capital, and ultimately decreased community resilience in terms of the ability to mobilize community resources toward meeting shocks and stresses. Indeed, resilience was low for the broader fishing community, illustrated by the lack of active fishing organizations to give a voice and agency at the community level. Lack of community collective action, such as poor participation in fisheries management, has also been observed by others working with the Caiçara (Leite and Gasalla 2013, Trimble 2013, Trimble et al. 2014, Bockstael et al. 2016). The absence of formal community-level institutions, known to be important for adaptation elsewhere (e.g., Blythe et al. 2014), as well as the disappearance of community-level informal support networks (such as multirões) indicate the absence of strong community cohesion in the study area. Low community cohesion, i.e., low social capital, means a missed opportunity for community resilience: "Social capital is a resource for action [that] lie[s] with 'relations' and the benefits that arise from these relations" (Trimble 2013:30); organizing with others in order to become an agent of one's own life is ultimately an act of empowerment (Jentoft 2007). Magis (2010) and Berkes and Ross (2013) similarly emphasized the roles of community agency, self-organizing, and drawing on community resources. Figure 2 attempts to organize and summarize the central findings regarding resilience features for the three levels.

A further finding of the present study is that persistence, adaptation, and transformation were related phenomena (and not alternatives) occurring simultaneously as fishers and their families responded to changes. Through the rapid conversion process from a resource-based and subsistence-oriented economy to a tourismorientated one, fishers, their households, and the broader community persisted, adapted, and were partially transformed. For example, many men persisted in fisheries by adapting their skills to include tourism as a part-time income source. At the same time, women began engaging in wage labor, e.g., working as housekeepers, adding up to a transformation. Many fishers themselves partially transformed their ways to accommodate the new lifestyle. As hired captains, the fishers had to accept the loss of being their own bosses, a defining characteristic of being a fisher (Johnson et al. 2018, Leite 2018). Even though some of the resilience literature tends to consider adaptability and transformability as distinct concepts (Walker et al. 2004), the 
results indicate a melding of persistence, adaptation, and transformation processes allowing resilience. Consistent with Béné et al. (2014) and Brown (2016), all three phenomena were taking place simultaneously among the fishing-dependent people in Ubatuba.

\section{CONCLUSIONS}

We argue the need for a more nuanced understanding of the relationships between different features of resilience at multiple levels of organization (individual, household, community). The nature of these interactions has represented a knowledge gap in the literature. This study of a coastal fishing community in Brazil offers three conclusions in furthering our understanding of multilevel resilience.

First, interactions among resilience features at individual, household, and community levels were not always consistent. Importantly, they included disjunctions, or negative connections, between features in one level and another. Further, lack of individual resilience did not necessarily translate into overall lower household resilience. Similarly, high household resilience did not translate into increased community resilience, and the lack of community resilience did not affect all households in the community equally.

Second, the higher resilience of certain groups within the fishing community contributed to increased social differentiation, ultimately undermining community resilience. Approaching resilience at multiple social levels revealed the complexities of dealing with social-ecological system resilience more broadly because resilience was not homogeneous within levels, nor among levels.

Third, understanding resilience at multiple levels highlighted the consideration of persistence, adaptation, and transformation processes as potentially complementary, rather than as conflicting or alternate processes. In this study all three processes frequently occurred simultaneously, as fishers, their families, and the broader fishing community responded to shocks, stresses, and new opportunities brought about by changes. Here transformation was an emergent process and incomplete, rather than a managed process as in Gelcich et al. (2010).

These findings together underline the risks of approaching socialecological system resilience without unraveling the particularities of specific social levels and actors, and the importance of unpacking resilience processes at various levels and exploring how they relate to one another. A multilevel approach allows insights into important aspects of resilience (or lack thereof) that would not be apparent if only one level were explored.

Last, resilience is always changing over time depending on the particular social, ecological, and political context. Shocks, stresses, and new opportunities, life and its adversities, as well as natural resources management policies and user-rights are all dynamic processes; as these change, resilience within and across social levels, and their interactions, is also likely to change.

Responses to this article can be read online at: http://www.ecologyandsociety.org/issues/responses. php/10910

\section{Acknowledgments:}

We would like to express our deepest gratitude to the fishing families of Lázaro and Saco da Ribeira, Ubatuba, Brazil, for kindly sharing their time, knowledge, and histories with us. The first author is thankful to Connor Jandreau for help with the project. We thank David Upcher for assistance with Figure 2. We appreciate funding from the Brazilian National Council for Scientific and Technological Development (CNPq); the IDRC/SSHRC International Research Chairs Initiative; and the Canada Research Chair in Community-Based Resource Management.

\section{LITERATURE CITED}

Abdallah, P. R., and U. R. Sumaila. 2007. An historical account of Brazilian public policy on fisheries subsidies. Marine Policy 31 (4):444-450. https://doi.org/10.1016/j.marpol.2007.01.002

Adger, W. N. 2000. Social and ecological resilience: are they related? Progress in Human Geography 24(3):347-364. https://doi. org/10.1191\%2F030913200701540465

Alinovi, L., M. D'Errico, E. Mane, and D. Romano. 2010. Livelihoods strategies and household resilience to food insecurity: an empirical analysis to Kenya. European Report on Development $1-52$.

Alinovi, L., E. Mane, and D. Romano. 2009. Measuring household resilience to food insecurity: application to Palestinian households. FAO Working Paper. Food and Agriculture Organization, Agricultural and Development Economics Division, Rome, Italy.

Allison, E. H., and F. Ellis. 2001. The livelihood approach and management of small-scale fisheries. Marine Policy 25:377-388. https://doi.org/10.1016/S0308-597X(01)00023-9

Badjeck, M.-C., E. H. Allison, A. S. Halls, and N. K. Dulvy. 2010. Impacts of climate variability and change on fishery-based livelihoods. Marine Policy 34:375-383. https://doi.org/10.1016/j. marpol.2009.08.007

Begossi, A. 1998. Resilience and neo-traditional populations: the Caiçaras (Atlantic Forest) and Caboclos (Amazon, Brazil). Pages 129-157 in F. Berkes, and C. Folke, editors. Linking social and ecological systems: management practices and social mechanisms for building resilience. Cambridge University Press, Cambridge, UK.

Begossi, A. 2006. Temporal stability in fishing spots: conservation and co-management in Brazilian artisanal coastal fisheries. Ecology and Society 11(5):5. https://doi.org/10.5751/ES-01380-110105

Béné C., K. Mindjimba, E. Belal, T. Jolley, and A. Neiland. 2003. Inland fisheries, tenure systems and livelihood diversification in Africa: the case of the Yaéré floodplains in Lake Chad Basin. African Studies 62(2):187-212. https://doi.org/10.1080/00020180$\underline{32000148759}$

Béné, C., A. Newsham, M. Davies, M. Ulricks, and R. GodfreyWood. 2014. Resilience, poverty and development. Journal of International Development 26:598-623. https://doi.org/10.1002/ jid.2992 
Berkes, F., and H. Ross. 2013. Community resilience: toward an integrated approach. Society and Natural Resources 26:5-20. https://doi.org/10.1080/08941920.2012.736605

Berkes, F., and H. Ross. 2016. Panarchy and community resilience: sustainability science and policy implications. Environmental Science \& Policy 61:185-193. https://doi.org/10.1016/j.envsci.2016.04.004

Bernard, H. R. 2006. Research methods in anthropology: qualitative and quantitative approaches. Fourth edition. Altamira Press, Walnut Creek, California, USA.

Blythe, J. L., G. Murray, and M. Flaherty. 2014. Strengthening threatened communities through adaptation: insights from coastal Mozambique. Ecology and Society 19(2):6. https://doi. org/10.5751/ES-06408-190206

Bockstael, E., N. C. F. Bahia, C. S. Seixas, and F. Berkes. 2016. Participation in protected area management planning in coastal Brazil. Environmental Science \& Policy 60:1-10. https://doi. org/10.1016/j.envsci.2016.02.014

Brown, K. 2014. Global environmental change I: a social turn for resilience? Progress in Human Geography 38(1):107-117. https:// doi.org/10.1177\%2F0309132513498837

Brown, K. 2016. Resilience, development and global change. Routledge, London, UK. https://doi.org/10.4324/9780203498095

Brown, K., and E. Westaway. 2011. Agency, capacity, and resilience to environmental change: lessons from human development, well-being, and disasters. Annual Review of Environment and Resources 36:321-342. https://doi.org/10.1146/ annurev-environ-052610-092905

Buikstra, E., H. Ross, C. A. King and P. G. Baker, D. Hegney, K. McLachlan, and C. Rogers-Clark. 2010. The components of resilience: perceptions of an Australian rural community. Journal of Community Psychology 38:975-991. https://doi.org/10.1002/ jcop.20409

Coulthard, S. 2008. Adapting to environmental change in artisanal fisheries - insights from a South Indian Lagoon. Global Environmental Change 18:479-489. https://doi.org/10.1016/j. gloenvcha.2008.04.003

Creswell, J. W. 2009. Research design: qualitative, quantitative, and mixed methods approaches. SAGE, Thousand Oaks, California, USA.

Degnbol, P., H. Gislason, S. Hanna, S. Jentoft, J. R. Nielsen, S. Sverdrup-Jensen, and D. C. Wilson. 2006. Painting the floor with a hammer: technical fixes in fisheries management. Marine Policy 30:534-543. https://doi.org/10.1016/j.marpol.2005.07.002

Diegues, A. C. 1974. A pesca em Ubatuba: estudo socioeconômico. Sudelpa, São Paulo, Brazil.

Diegues, A. C. 1983. Pescadores, camponeses e trabalhadores do mar. Editora Atica, Sao Paulo, Brazil.

Diegues, A. C. 2004. A pesca construindo sociedades. Núcleo de Apoio à Pesquisa sobre Populações Humanas e Áreas Úmidas Brasileiras. USP, São Paulo, Brazil.

Ellis. F. 2000. Rural livelihoods and diversity in developing countries. Oxford University Press, Oxford, UK.
Folke, C. 2006. Resilience: the emergence of a perspective for social-ecological systems analyses. Global Environmental Change 16(3):253-267. https://doi.org/10.1016/j.gloenvcha.2006.04.002

Folke, C., S. R. Carpenter, B. Walker, M. Scheffer, T. Chapin, and J. Rockström. 2010. Resilience thinking: integrating resilience, adaptability and transformability. Ecology and Society 15(4):20. https://doi.org/10.5751/ES-03610-150420

Gelcich, S., T. P. Hughes, P. Olsson, C. Folke, O. Defeo, M. Fernández, S. Foale, L. H. Gunderson, C. Rodríguez-Sickert, M. Scheffer, R. S. Steneck, and J. C. Castilla. 2010. Navigating transformations in governance of Chilean marine coastal resources. Proceedings of the National Academy of Sciences of the United States of America 107(39):16794-16799. https://doi. org/10.1073/pnas.1012021107

Grant, S. C., F. Berkes, and J. Brierly. 2007. Understanding the local livelihoods system in resource management: the pelagic longline fishery in Gouyave, Grenada. Gulf and Caribbean Research 19(2):113-122. https://doi.org/10.18785/gcr.1902.14

Gunderson, L., and C. Holling. 2002. Panarchy: understanding transformations in human and natural systems. Island, Washington, D.C., USA.

Hanazaki, N., F. Berkes, C. S. Seixas, and N. Peroni. 2013. Livelihood diversity, food security and resilience among the Caiçara of coast Brazil. Human Ecology 41:153-164. https://doi. org/10.1007/s10745-012-9553-9

Hay, I. 2008. Qualitative research methods in human geography. Second edition. Oxford University Press, Melbourne, Australia.

Idrobo, C. J. M. 2014. Ponta Negra ethnoecology of practice: intergenerational knowledge continuity in the Atlantic forest coast of Brazil. Dissertation. University of Manitoba, Winnipeg, Manitoba, Canada.

Islam, M. M., and R. Chuenpagdee. 2013. Negotiating risk and poverty in mangrove fishing communities of the Bangladesh Sundarbans. Maritime Studies 12:7. https://doi.org/10.1186/2212-9790-12-7

Jentoft, S. 2007. In the power of power: the understated aspect of fisheries and coastal management. Human Organization 66 (4):426-437. https://doi.org/10.17730/humo.66.4.a836621h2k5x46m2

Jentoft, S., and R. Chuenpagdee, editors. 2015. Interactive governance for small-scale fisheries. Global reflections. MARE Publication Series 13. Springer, Cham, Switzerland. https://doi. org/10.1007/978-3-319-17034-3

Johnson, D. S., T. G. Acott, N. Stacey, and J. Urquhart, editors. 2018. Social wellbeing and the values of small-scale fisheries. MARE Publications Series 17. Springer, Cham, Switzerland. https://doi.org/10.1007/978-3-319-60750-4

Leite, M. C. F. 2018. Bridging multi-level resilience and wellbeing: a study of small-scale fisher responses to change in Southeastern Brazil. Dissertation. University of Manitoba, Winnipeg, Manitoba, Canada.

Leite, M. C. F., and M. A. Gasalla 2013. A method to assessing fisher's ecological knowledge as a practical tool for ecosystembased fisheries management: seeking consensus in southeastern 
Brazil. Fisheries Research 145:43-53. https://doi.org/10.1016/j. fishres.2013.02.013

Luthar, S. S. 2006. Resilience in development: a synthesis of research across five decades. Pages 739-795 in D. Cicchetti and D. J. Cohen, editors. Developmental psychopathology: risk, disorder, and adaptation. John Wiley \& Sons, Hoboken, New Jersey, USA. https://doi.org/10.1002/9780470939406.ch20

Maclean, K., M. Cuthill, and H. Ross. 2014. Six attributes of social resilience. Journal of Environmental Planning and Management 57(1):144-156. https://doi.org/10.1080/09640568.2$\underline{013.763774}$

Magis, K. 2010. Community resilience: an indicator of social sustainability. Society and Natural Resources 23:401-416. https:// doi.org/10.1080/08941920903305674

Marschke, M. J., and F. Berkes. 2006. Exploring strategies that build livelihoods resilience: a case from Cambodia. Ecology and Society 11(1):42. https://doi.org/10.5751/ES-01730-110142

Masten, A. S., and J. Obradović. 2006. Competence and resilience in development. Annals of the New York Academy of Science 1094:13-27. https://doi.org/10.1196/annals.1376.003

Nguyen, K. V., and H. James. 2013. Measuring household resilience to floods: a case study in the Vietnamese Mekong River Delta. Ecology and Society 18(3):13. http://dx.doi.org/10.5751/ ES-05427-180313

Opiyo, F. E. O., O. V. Wasonga, and M. N. Nyangito. 2014. Measuring household vulnerability to climate-induced stresses in pastoral rangelands of Kenya: implication for resilience programming. Pastoralism 4:10. https://doi.org/10.1186/ $\underline{\text { 13570-014-0010-9 }}$

Prado, D. S., C. S. Seixas, and F. Berkes. 2015. Looking back and looking forward: exploring livelihood change and resilience building in a Brazilian coastal community. Ocean \& Coastal Management 113:29-37. https://doi.org/10.1016/j.ocecoaman.2015.05.018

Ross, H., and F. Berkes. 2014. Research approaches for understanding, enhancing, and monitoring community resilience. Society and Natural Resources 27:787-804. https://doi. org/10.1080/08941920.2014.905668

Schoon, I. 2006. Risk and resilience: adaptation in changing times. Cambridge University Press, Cambridge, UK. https://doi. org/10.1017/CBO9780511490132

Trimble, M. 2013. Towards adaptive co-management of artisanal fisheries in coastal Uruguay: analysis of barriers and opportunities, with comparisons to Paraty (Brazil). Dissertation. University of Manitoba, Winnipeg, Manitoba, Canada.

Trimble, M., L. G. de Araujo, and C. S. Seixas. 2014. One party does not tango! Fishers' non-participation as a barrier to comanagement in Paraty, Brazil. Ocean \& Coastal Management 92:9-18. https://doi.org/10.1016/j.ocecoaman.2014.02.004

Trimble, M., and D. Johnson. 2013. Artisanal fishing as an undesirable way of life? The implications for governance of fisher's wellbeing aspirations in coastal Uruguay and southeastern Brazil. Marine Policy 37:37-44. https://doi. org/10.1016/j.marpol.2012.04.002
Turner, B. L., R. E. Kasperson, P. A. Matson, J. J. McCarthy, R. W. Corell, L. Christensen, N. Eckley, J. X. Kasperson, A. Luers, M. L. Martello, C. Polsky, A. Pulsipher, and A. Schiller. 2003. A framework for vulnerability analysis in sustainability science Proceedings of the National Academy of Sciences of the United States of America 100(14):8074-8079. https://www.pnas.org/ content/100/14/8074 https://doi.org/10.1073/pnas.1231335100

Walker, B., C. S. Holling, S. R. Carpenter, and A. Kinzig. 2004. Resilience, adaptability and transformability in social-ecological systems. Ecology and Society 9(2):5. https://doi.org/10.5751/ ES-00650-090205

Wright, M. O., A. S. Masten, and A. J. Narayan. 2013. Resilience processes in development: four waves of research on positive adaptation in the context of adversity. Pages 15-37 in S. Goldstein and R. B. Brooks editors. Handbook of resilience in children. Springer Science Business Media, New York, NY, United States. http://dx.doi.org/10.1007/978-1-4614-3661-4_2 